\title{
Fostering character strengths to promote thriving and flourishing in organizations
}

\author{
Claudia Harzer
}

Published online: 6 February 2020

(C) The Author(s) 2020

\begin{abstract}
Character strengths are positively valued personality traits that find expression in individuals' thoughts, feelings, and behaviors. Most adults develop up to seven core character strengths (i.e., "signature strengths") which are central to their identity. According to fundamental theoretical assumptions about signature strengths, Person-Environment Fit Theory, Job Demands-Resources Theory and prior empirical research, employing one's signature strengths leads to a number of favorable general and work outcomes. Strategies on the individual, team, and organizational level fostering signature strengths use in the workplace are summarized.
\end{abstract}

Keywords Character strengths $\cdot$ signature strengths $\cdot$ coaching

\section{Charakterstärken als Ansatzpunkt zur Förderung des persönlichen Wachstums in Organisationen}

Zusammenfassung Charakterstärken sind positiv bewertete Persönlichkeitsmerkmale, die sich im individuellen Denken, Fühlen und Verhalten widerspiegeln. Erwachsene entwickeln meist bis zu sieben Kerncharakterstärken, sogenannte „Signaturstärken“, die besonders zentral für sie sind. Entsprechend theoretischen Annahmen zu Signaturstärken, Person-Environment Fit Theorie und Job DemandsResources Theorie sowie Forschungsbefunden führt die Anwendung der Signaturstärken zu zahlreichen gewünschten allgemeinen und berufsbezogenen Outcomes. Strategien auf individueller, Team- und Organisationsebene zur Erhöhung der Anwendung der Signaturstärken im Beruf werden zusammengefasst.

Schlüsselwörter Charakterstärken $\cdot$ Signaturstärken $\cdot$ Coaching

Dr. C. Harzer $(\bowtie)$

Institut für Psychologie, Universität Greifswald, Franz-Mehring-Str. 47, 17489 Greifswald, Germany

E-Mail: contact@ strengths-at-work.org 
The goal of this special issue is to provide insights into individual and organizational strategies and interventions which may foster individual growth, flourishing, and thriving at work. Individual growth, flourishing, and thriving at work are very broadly construed in this paper, and include improvements in subjective and psychological well-being (Harzer 2016, 2017a) as well as increases in performance and proficiency on the individual, team, and organizational level (Harzer et al. 2017; Harzer und Ruch 2014). The present paper aims to summarize and discuss relevant strategies and interventions on the individual, team, and organizational level to promote the use of character strengths in the workplace, which should in turn increase individual growth, flourishing, and thriving at work.

\section{Character Strengths}

Character strengths number among the core concepts in the field of positive psychology. Research in the field of positive psychology focuses on studying factors that help individuals, groups, and institutions thrive (Seligman und Csikszentmihalyi 2000). Peterson and Seligman (2004) defined character strengths as individual differences that are positively valued across culture and that find expression in individuals' thoughts (e.g., considering the consequences of one's behavior before acting), feelings (e.g., enjoying teamwork), and behaviors (e.g., engaging in learning activities). Character strengths are trait-like personality characteristics; they exhibit a reasonable amount of stability over time and situations, but they are nevertheless influenced by life circumstances and might therefore change over the life course or as the result of training (cf. Gander et al. 2019).

Character strengths differ from personality traits like the Big Five in several aspects. Positively valued, desirable traits were intentionally excluded from the Big Five tradition, as Allport (1937) regarded character traits (i.e., valued traits) as unnecessary to describe personality. Furthermore, character strengths address a number of criteria (e.g., they are cross-culturally valued and contribute to living a fulfilled life; cf. Peterson and Seligman 2004) that are not successfully applicable to personality traits. Nevertheless, some character strengths do overlap meaningfully with selected Big Five traits (e.g., perseverance as a character strength and conscientiousness as a Big Five trait), but the size of the correlation coefficients indicates that the concepts are unique despite some overlapping aspects. Moreover, some character strengths go beyond the traditional Big Five. Peterson and Seligman (2004) identified and categorized 24 character strengths in their Values in Action (VIA) classification of strengths, which was derived from an extensive literature review on positive traits (see Table 1).

The character strengths shown in Table 1 are distinct from one another and measurable. There are several measurement instruments aiming to assess the 24 character strengths; the Values in Action Inventory of Strengths (VIA-IS; Peterson et al. 2005; German version: Ruch et al. 2010) is a self-rating questionnaire that is most often used to assess the character strengths in adults. Various studies have shown its satisfactory reliability and validity. 
Table 1 The 24 Character Strengths Included in the Values in Action Classification of Strengths (Peterson and Seligman 2004) and Short Descriptions Defining the Strengths

\section{Cognitive strengths that entail the acquisition and use of knowledge-strengths of wisdom and knowledge}

Creativity [originality, ingenuity]: Thinking of novel and productive ways to conceptualize and do things; includes but is not limited to artistic achievement

Curiosity [interest, novelty-seeking, openness to experience]: Taking an interest in all of ongoing experience for its own sake; finding subjects and topics fascinating; exploring and discovering

Judgment [open-mindedness, critical thinking]: Thinking things through and examining them from all sides; not jumping to conclusions; being able to change one's mind in light of evidence; weighing all evidence fairly

Love of learning: Mastering new skills, topics, and bodies of knowledge, whether on one's own or through formal instruction; related to curiosity but goes beyond it to describe the tendency to systematically add to what one knows

Perspective [wisdom]: Being able to provide wise counsel to others; having ways of looking at the world that make sense to oneself and to others

\section{Emotional strengths that involve the exercise of will to accomplish goals in the face of opposition, external or internal-strengths of courage}

Bravery [valor]: Not shrinking from threat, challenges, difficulty, or pain; speaking up for what is right even in the face of opposition; acting on one's convictions even if unpopular; includes but is not limited to physical bravery

Perseverance [persistence, industriousness]: Finishing what one starts; persisting in a course of action in spite of obstacles; "getting it out the door"; taking pleasure in completing tasks

Honesty [authenticity, integrity]: Speaking the truth but also more broadly presenting oneself and acting in a genuine and sincere way; being without pretense; taking responsibility for one's feelings and actions Zest [vitality, enthusiasm, vigor, energy]: Approaching life with excitement and energy; not doing things halfway or halfheartedly; living life as an adventure; feeling alive and activated

\section{Interpersonal strengths that involve "tending and befriending" others-strengths of humanity}

Capacity to love and be loved [short name: love]: Valuing close relations with others, in particular those in which sharing and caring are reciprocated; being close to people

Kindness [generosity, nurturing, care, compassion, altruistic love, "niceness"]: Doing favors and good deeds for others; helping them; taking care of them

Social intelligence [emotional intelligence, personal intelligence]: Being aware of the motives and feelings of other people and oneself; knowing what to do to fit into different social situations; knowing what makes other people tick

\section{Civic strengths that underlie healthy community life-strengths of justice}

Teamwork [citizenship, social responsibility, loyalty]: Working well as a member of a group or team; being loyal to the group; doing one's share

Fairness: Treating all people the same according to notions of fairness and justice; not letting personal feelings bias one's decisions about others; giving everyone a fair chance

Leadership: Encouraging a group of which one is a member to get things done and at the same time maintain good relations within the group; organizing group activities and seeing that they happen

\section{Strengths that protect against excess-strengths of temperance}

Forgiveness [mercy]: Forgiving those who have done wrong; accepting the shortcomings of others; giving people a second chance; not being vengeful

Modesty [humility]: Letting one's accomplishments speak for themselves; not regarding oneself as more special than one is

Prudence: Being careful about one's choices; not taking undue risks; not saying or doing things that one might later regret

Self-regulation [self-control]: Regulating what one feels and does; being disciplined; controlling one's appetites and emotions 
Table 1 (Continued)

\section{Strengths that forge connections to the larger universe and provide meaning-transcendence/ theological strengths}

Appreciation of beauty and excellence [awe, wonder, elevation; short name: appreciation]: Noticing and appreciating beauty, excellence, and/or skilled performance in various domains of life, from nature to art to mathematics to science to everyday experience

Gratitude: Being aware of and thankful for the good things that happen; taking time to express thanks Hope [optimism, future-mindedness, future orientation]: Expecting the best in the future and working to achieve it; believing that a good future is something that can be brought about

Humor [playfulness]: Liking to laugh and tease; bringing smiles to other people; seeing the light side of life; making (not necessarily telling) jokes

Spirituality [religiousness, faith, purpose]: Having coherent beliefs about the higher purpose and meaning of the universe; knowing where one fits within the larger scheme of things; having beliefs about the meaning of life that shape one's conduct and provide comfort

Note. The character strengths are grouped together theoretically based on their content. The labels and expressions in brackets emphasize the family resemblance among the concepts to acknowledge the heterogeneity of strengths and minimize subtle (political or otherwise) connotations (Peterson and Seligman 2004).

Per definition, character strengths contribute to individuals' fulfillment, flourishing, and thriving (Peterson and Seligman 2004). Accordingly, research has shown meaningful relations between specific character strengths and favorable outcomes in different areas of life, including physical health, life satisfaction, psychological well-being, and young people's school achievement and vocational orientation (e.g., Harzer 2016; Park et al. 2004; Proyer et al. 2012, 2013; Weber 2018).

Several studies highlight the role of character strengths in the work context. Higher scores in character strengths were associated with higher scores in beneficial work outcomes like positive affect, work engagement, sense of meaning, job satisfaction, and lower stress (e.g., Harzer et al. 2017; Harzer and Ruch 2015; Heintz and Ruch 2019). Furthermore, associations between character strengths and various dimensions of job performance have been found (e.g., Avey et al. 2012; Harzer et al. 2019; Kalyar and Kalyar 2018; Littman-Ovadia and Lavy 2016). Specifically, higher scores in character strengths were positively related to in-role behavior (also known as task performance), extra-role behavior (also known as contextual performance or organizational citizenship behavior), and creative performance. Furthermore, character strengths were negatively related to counterproductive work behavior (also known as deviant behavior). Different sets of character strengths were relevant predictors for different outcomes. For example, modesty especially mattered with respect to counterproductive work behavior; zest, teamwork, and social intelligence were important predictors of in-role and extra-role performance. Therefore, it is useful to keep in mind that different character strengths matter in different contexts. However, it is not feasible or functional for coaching, team supervision or organizational consulting to attempt to promote all 24 character strengths. Instead, signature strengths might be a much more meaningful leverage point. 


\section{Signature Strengths and Their Use}

Character strengths can be ranked with respect to how central they are to a given person on the individual level. Most adults develop up to seven core character strengths that are most central to them and their identity; these character strengths are called "signature strengths" (Peterson and Seligman 2004). It is argued that the use of one's signature strengths is fulfilling and satisfying. Specifically, when using a signature strength, individuals are expected to experience:

a) a sense of authenticity,

b) feelings of excitement, as applying one's signature strengths is energizing and invigorating rather than exhausting,

c) intrinsic motivation, a sense of yearning and a feeling of inevitability to act in accordance with one's signature strengths, as well as

d) a rapid learning curve as well as continuously learning of ways to employ one's signature strengths (Peterson and Seligman 2004).

One might question the existence of a concept like signature strengths. However, it has been shown that individuals' application of their highest-ranked character strengths was more strongly related to positive experiences at work (i.e., job satisfaction, enjoyment, and engagement at work) than the application of lower-ranked strengths (Harzer and Ruch 2013). Therefore, work-related activities (like one's work tasks) and environments (like one's workplace and employing organization) that provide employees with opportunities to use their individual signature strengths should be the most fulfilling and valued by employees. Prominent approaches can provide the theoretical backbone for this assumption: Person-Environment (PE) Fit Theory (e.g., Caplan 1987; Kristof-Brown and Billsberry 2013) and Job DemandsResources (JD-R) Theory (Bakker and Demerouti 2017).

The underlying assumption of PE-Fit Theory is that the closer the match between the person (e.g., in terms of personality, abilities, interests, values etc.) and the environment (e.g., job tasks, organizational culture), the better the outcomes for employees and the higher the likelihood of employee thriving. The congruence between job tasks and individuals' signature strengths can be subsumed under the concept of complementary person-job fit (cf. Kristof 1996), which represents the degree to which a job and an individual each supply what the other needs. An individual's signature strengths create a need to be allowed to behave in congruence with these strengths. A job fulfills this need to the extent to which job tasks allow the individual to employ their signature strengths (cf. Harzer 2017b), and the closeness of the match should be related to positive work-related outcomes.

The role of individual capacities in outcomes such as work engagement, burnout, and job performance in the face of job demands has also been highlighted in the $J D-R$ Theory. Character strengths and signature strengths can be considered personal resources within the framework of JD-R Theory. The application of signature strengths may be seen as the fit between an individual's personal resources (i.e., signature strengths) and job resources (i.e., the job allows and fosters the use of signature strengths) but also as the fit between personal resources (i.e., signature strengths) and job demands (i.e., job tasks demand the use of these signature 
strengths). According to JD-R Theory, employing one's signature strengths may foster work motivation which in turn leads to better job performance, decreases strain, and buffers the negative effects of demands on strain.

In line with the assumptions of PE-Fit Theory and JD-R Theory, research has repeatedly shown that the use of one's signature strengths at work is positively related to favorable work outcomes. For example, signature strengths use was positively related to positive affect at work, job satisfaction, meaning, engagement, sense of accomplishment, calling, and job performance (e.g., Harzer et al. 2017; Harzer and Ruch 2012, 2016; Littman-Ovadia et al. 2017). All of these outcomes can be seen as aspects of individual growth, flourishing, and thriving at work broadly construed.

\section{Fostering Signature Strengths Use on the Individual, Team, and Organizational Level}

Focusing on individuals' signature strengths rather than specific character strengths like teamwork or leadership offers a unique way to acknowledge diversity among the workforce (here: diversity regarding personality). Employees tend to strongly appreciate this approach (i.e., participants in trainings regularly say things like "finally there is a program that really is about me"). However, both PE-Fit Theory and JD$\mathrm{R}$ Theory also highlight the role of environmental influences on signature strengths use. Therefore, in order to foster signature strengths use, it is not only relevant to identify individuals' signature strengths but to provide and develop opportunities for them to apply these signature strengths; this is especially relevant in the context of coaching, team supervision or organizational consulting.

\subsection{Individual Level}

The literature identifies at least three different ways of fostering signature strengths use on the individual level. These are:

1. coaching (e.g., Biswas-Diener 2010; Govindji and Linley 2007; McQuaid 2017),

2. interventions (e.g., Dubreuil et al. 2016; Ghielen et al. 2018; Harzer and Ruch 2016), and

3. leadership style of managers (e.g., Kong and Ho 2016; Lavy et al. 2017; Meyers et al. 2019b).

Strengths coaching aims at enabling clients to make informed decisions and choices about which strengths to use in what way in specific situations and contexts to reach set goals. McQuaid (2017) provides a thorough overview of how strengthsbased coaching might work in practice. She identifies several fundamental steps, specifically (1) discovering the best of the past, (2) dreaming of what is possible in the future, (3) designing pathways forward, and (4) delivering on the desired changes. Step 1 includes discovering one's own signature strengths by filling in the VIA-IS and identifying when and how one currently applies them (for example at work). For example, a client might discover that leadership and perseverance are among her signature strengths, and that even though she does not have a formal leadership 
position, she often is responsible for organizing her team's work and making sure plans are put into action. In Step 2, clients may imagine their best possible future self and what their life would be like if they increased their use of their signature strengths. For example, a client might dream about having a leadership position as well as to be less stressed at work due to anxiety about making mistakes (even though she almost never makes mistakes) in order to become a more positive, constructive leader. Step 3 focuses on identifying goals and potential pathways to reaching these goals by using one's signature strengths as well as obstacles that may arise and how they can be overcome by using one's signature strengths. For example, a client's goals might be getting a promotion to a leadership position as well as being more relaxed at work. As possible pathways to reaching these goals, she may identify participating in her employer's leadership development program in order to be considered for leadership positions, as well as an increased use of another of her signature strengths, namely humor, in order to see the light side and become less anxious about making mistakes. Next, clients must prepare for Step 4, which involves enacting the plans made in Step 3. Clients are asked to identify small daily steps along their chosen pathway in order to ensure that their plans are carried out. For example, the client in the example above might start by identifying the steps needed to enroll in the leadership development program. During Step 4, coaching aims to review the clients' habits with respect to signature strengths use and their progress towards goal attainment as well as to explore whether any adjustments are needed in the client's signature strengths use in order to tackle current and potential future setbacks. Additionally, the progress already achieved is celebrated, and steps are taken to ensured that the client is ready to make further progress independently (McQuaid 2017). Research has shown that this kind of coaching can lead to increases in goal progress, need satisfaction, and subjective well-being (e.g., Linley et al. 2010).

Interventions (which may be part of personnel development programs) usually seek to increase employees' use of their signature strengths at work. They typically follow sequence plans which include (1) identifying one's signature strengths (e.g., by filling in the VIA-IS), (2) identifying one's daily activities and tasks at work, (3) determining the current frequency and ways one's uses of one's signature strengths in daily activities and tasks at work, (4) developing of if-then-plans about how to use one's signature strengths in new and different ways in daily activities and tasks at work, (5) putting these plans into action, and (6) evaluating one's progress. These steps are very similar to the coaching process described above but are worked through with a group of employees during a series of workshops (or online) rather than individually. For example, a team leader might identify modesty, honesty, humor, and kindness among his signature strengths after carefully studying his rank order of character strengths and the definitions of the character strengths. After listing all of his work tasks (e.g., coordinating team tasks, performance reviews of team members) and thinking about how he uses his signature strengths at work, he realizes that he rarely uses modesty and humor at work. He wants to change that. As performance reviews need to be completed in the near future and he usually does not like them because he is rarely able to create an authentic and constructive atmosphere during these meetings with his subordinates, he wants to use his signature 
strengths to improve these meetings. Specifically, he wants to use his modesty in combination with honesty to talk more authentically and openly about positive and negative aspects of his subordinates' job performance. If the situation gets tense, he wants to use his humor and kindness to lighten up the situation and thus make sure it stays constructive and open. He was able to put those plans into action and realized that not only did he feel more authentic and comfortable during the performance reviews, his subordinates told him they were more satisfied as well. Research on the impact of interventions showed that they led to an increase in outcomes like positive affect, calling, self-efficacy, personal growth, life satisfaction, and work engagement as well as to a decrease in burnout, partially mediated by the changes in positive affect (e.g., Dubreuil et al. 2016; Harzer and Ruch 2016; Meyers and van Woerkom 2017; van Woerkom and Meyers 2019).

Managers have a critical impact on their individual subordinates (e.g., Montano et al. 2017). According to Meyers et al. (2019b), managers may be able to foster their subordinates' use of their signature strengths through their behavior in several ways. For example, when managers allowed their subordinates autonomy, subordinates were more likely to use their strengths (Kong and Ho 2016). This means that if managers give their subordinates enough space (i.e., autonomy), they are more likely to behave authentically with respect to their signature strengths. Additionally, managers who are good at spotting and communicating others' strengths might increase their subordinates' awareness of their own signature strengths. This increased awareness of their signature strengths should also make employees more likely to apply them. Furthermore, managers may support their subordinates' personal growth by engaging strengths-based coaching. For example, performance reviews could focus on employees' individual strengths and how to promote them. Research has shown that employees working with managers who focus on their subordinates' strengths experience less employee turnover and higher levels of employee productivity (Clifton and Harter 2003). Therefore, leadership development programs may also wish to consider these aspects of leadership behavior in order to foster employees' signature strengths use.

\subsection{Team Level}

The core goals of interventions targeting signature strengths use on the team level are gaining an awareness of and coordinating each team member's signature strengths while allocating specific tasks and managing team projects (Meyers et al. 2019b). Team-based interventions can encompass the five central steps of (1) preparation, (2) identification, (3) integration, (4) action, and (5) evaluation (Miglianico et al. 2019). Step 1, preparation, includes psychoeducation to introduce the strengths approach (e.g., defining character and signature strengths and summarizing of important empirical results) as well as information on the intervention process in order to ensure buy-in from all team members. Step 2, identification, seeks to help each team member identify their individual signature strengths by filling in relevant measures (e.g., VIA-IS) and reflecting upon the results in order to ensure that each team member has a deep understanding of his or her own individual signature strengths. During Step 3, integration, each team member humbly presents his or her own in- 
dividual signature strengths and the team as a whole identifies examples of where these signature strengths could be observed during work and how they contributed to team performance. The goal of this step is to create a mutual awareness in the team of each member's signature strengths and provide vivid examples of how they shape daily experiences at work. These experiences can relate to signature strengths of one team member (e.g., "Your humor really helped to reduce the tension in this situation"), but also to several team members' signature strengths working in combination (e.g., "If you hadn't been so perseverant and you hadn't been so hopeful, we would never have managed to complete that project on time"). This is a very powerful step that is also beneficial for team building processes. Team members get to know each other better by sharing what they are best at and how that positively influences the team. This exchange among team members is typically very positive, open, welcoming, and cheerful. Step 4, action, is all about coordinating strengths; team members take responsibility for and create a joint plan for how to make the most of each team member's signature strengths. Such plans may include allocating different tasks within project to specific team members based on their signature strengths or ensuring that team members with complementary strengths work together to increase efficacy. During Step 5, evaluation, the use of team members' strengths is monitored, and any necessary adjustments are made in order to maintain performance. At regular meetings, team members jointly reflect upon existing plans, how they were put into action, whether or not the intended goals were reached, and whether or not adjustments are needed. Monitoring is necessary to maintain initial improvements (e.g., Dubreuil et al. 2016; Harzer and Ruch 2016).

\subsection{Organizational Level}

One way to foster strengths use on the organizational level is to develop and establish perceived organizational support. Perceived organizational support for strengths use is a specific form of perceived organizational support. Employees perceive organizational support when they experience the organization's policies, procedures, and practices as benevolent (Eisenberger et al. 1986). Similarly, when employees experience the organization's policies, procedures, and practices regarding employing one's strengths at work as benevolent, they perceive organizational support for strengths use (e.g., Meyers et al. 2019a; van Woerkom et al. 2016).

Perceived organizational support for strengths use may be established through human resource management practices (Dubreuil and Forest 2017). For example, during the recruitment process, individuals can be placed in specific roles within the company based on the fit between their individual signature strengths and the expected job roles, functions, or tasks. Formal personnel development and team building programs may also include strengths coaching and interventions. Yearly performance reviews can address employees' individual signature strengths and how they are applied on a daily basis at work.

One previous study showed that a strengths-based approach in performance reviews led to a $36 \%$ increase in performance whereas a deficit orientation led to a decrease of nearly 27\% (Corporate Leadership Council 2002). Research has also shown that higher perceived organizational support for strengths use goes along with 
higher work engagement, job performance, and life satisfaction as well as lower burnout (e.g., Botha and Mostert 2014; Meyers et al. 2020, 2015). Furthermore, perceived organizational support for strengths use buffered the effect of increasing workload on absenteeism (van Woerkom et al. 2016). Therefore, establishing practices on organizational level that foster strengths use seems highly relevant.

\section{Summary and Conclusion}

Most adults develop up to seven core character strengths that are most central to them and to their identity; these character strengths are called "signature strengths". When using their signature strengths, individuals experience a sense of authenticity and feel invigorated. Signature strengths use at work is related to various work-related outcomes such as job performance, work engagement, calling, and personal growth. Therefore, fostering employees' use of their signature strengths is an important leverage point for organizations to nurture employees' individual growth, flourishing, and thriving at work.

Several strategies on individual, team, and organization level that have been shown to foster strengths use and its outcomes were presented. Most of these strategies shared five basic ideas and steps: (1) psychoeducation on the meaning of signature strengths (use), (2) identifying signature strengths, (3) creating an awareness of signature strengths use, (4) planning of meaningful future signature strengths use, and (5) evaluating and monitoring of progress and making needed adjustments.

However, a few words of caution need to be mentioned as well. Like all approaches, the strengths approach is not a universal remedy. For example, an individual's level of knowledge and education need to fit their work demands in order to ensure a basic level of job performance. Moreover, when an individual is experiencing psychopathological issues, these need to be addressed first with appropriate methods such as psychotherapy. Furthermore, the strengths approach can be combined with other approaches. Finally, character strengths and the use of signature strengths are all about balance and the healthy mean. The literature often highlights that it is important for clients to understand how strengths can be overplayed and underplayed (e.g., Linley 2008; McQuaid 2017). By definition, overplayed/underplayed behavior would no longer be in line with a character strength or signature strength. This issue needs to be addressed to ensure that clients have an awareness and understanding of how to meaningfully dose out and integrate strengths in a given situation.

There is a growing amount of evidence-based practice around the world incorporating the strengths-based approach into daily organizational practices. My sincere hope is such practices and their scientific evaluation further increase in Germany and in Europe as a whole. 
Funding Open Access funding provided by Projekt DEAL.

Open Access This article is licensed under a Creative Commons Attribution 4.0 International License, which permits use, sharing, adaptation, distribution and reproduction in any medium or format, as long as you give appropriate credit to the original author(s) and the source, provide a link to the Creative Commons licence, and indicate if changes were made. The images or other third party material in this article are included in the article's Creative Commons licence, unless indicated otherwise in a credit line to the material. If material is not included in the article's Creative Commons licence and your intended use is not permitted by statutory regulation or exceeds the permitted use, you will need to obtain permission directly from the copyright holder. To view a copy of this licence, visit http://creativecommons.org/licenses/by/4. $0 /$.

\section{References}

Allport, G. W. (1937). Personality: a psychological interpretation. Oxford: Holt.

Avey, B. J., Luthans, F., Hannah, S. T., Sweetman, D., \& Peterson, C. (2012). Impact of employees' character strengths of wisdom on stress and creative performance. Human Resource Management Journal, 22, 165-181. https://doi.org/10.1111/j.1748-8583.2010.00157.x.

Bakker, A. B., \& Demerouti, E. (2017). Job demands-resources theory: taking stock and looking forward. Journal of Occupational Health Psychology, 22, 273-285. https://doi.org/10.1037/ocp0000056.

Biswas-Diener, R. (2010). Practicing positive psychology coaching: assessment, activities and strategies for success. Hoboken: John Wiley \& Sons.

Botha, C., \& Mostert, K. (2014). A structural model of job resources, organisational and individual strengths use and work engagement. SA Journal of Industrial Psychology, 40, a1135. https://doi.org/ 10.4102/sajip.v40i1.1135.

Caplan, R.D. (1987). Person-environment fit theory and organizations: commensurate dimensions, time perspectives, and mechanisms. Journal of Vocational Behavior, 31, 248-267. https://doi.org/10.1016/ 0001-8791(87)90042-X.

Clifton, D. O., \& Harter, J. K. (2003). Investing in strengths. In K. S. Cameron, J. E. Dutton \& R. E. Quinn (Eds.), Positive organizational scholarship (pp. 111-121). San Francisco: Berrett-Koehler.

Corporate Leadership Council (2002). Building the high-performance workforce: a quantitative analysis of the effectiveness of performance management strategies. Washington, D.C.: Corporate Executive Board.

Dubreuil, P., \& Forest, J. (2017). Choose a job you love, and you will never have to work a day in your life: A strengths-based leadership approach to optimal functioning at work. In K. Kelloway, K. Nielsen \& J. Dimoff (Eds.), Leading to Occupational Health and Safety (pp. 281-306). Toronto: Wiley-Blackwell.

Dubreuil, P., Forest, J., Gillet, N., Fernet, C., Thibault-Landry, A., Crevier-Braud, L., \& Girouard, S. (2016). Facilitating well-being and performance through the development of strengths at work: Results from an intervention program. International Journal of Applied Positive Psychology, 1, 1-19. https://doi.org/10.1007/s41042-016-0001-8.

Eisenberger, R., Huntington, R., Hutchison, S., \& Sowa, D. (1986). Perceived organizational support. Journal of Applied Psychology, 71, 500-507. https://doi.org/10.1037/0021-9010.71.3.500.

Gander, F., Hofmann, J., Proyer, R. T., \& Ruch, W. (2019). Character strengths - stability, change, and relationships with well-being changes. Applied Research in Quality of Life. https://doi.org/10.1007/ s11482-018-9690-4.

Ghielen, S.T.S., van Woerkom, M., \& Meyers, M.C. (2018). Promoting positive outcomes through strengths interventions: a literature review. Journal of Positive Psychology, 13, 573-585. https://doi. org/10.1080/17439760.2017.1365164.

Govindji, R., \& Linley, A. (2007). Strengths use, self-concordance and well-being: implications for strengths coaching and coaching psychologists. International Coaching Psychology Review, 2, $143-153$.

Harzer, C. (2016). The eudaimonics of human strengths: the relations between character strengths and well-being. In J. Vitters $\emptyset$ (Ed.), International handbooks of quality-of-life. Handbook of eudaimonic well-being (pp. 307-322). Cham: Springer. https://doi.org/10.1007/978-3-319-42445-3. 
Harzer, C. (2017a). Positive Psychologie: Eine allgemeine Einführung und Zusammenfassung der Forschung [Positive Psychology: a general introduction and summary of research. Organisationsberatung, Supervision, Coaching, 24, 253-267. https://doi.org/10.1007/s11613-017-0509-1.

Harzer, C. (2017b). Charakterstärkenbezogener Personen-Job-Fit: Definition, Messung und Befunde zur Rolle für das individuelle Erleben und Verhalten im beruflichen Alltag (Character strengths-related person-job-fit: Definition, operationalization, and empirical research on its role for individual experiences and behavior at work). In M. Brohm-Badry, C. Peifer, \& J. M. Greve (Eds.), Positiv-Psychologische Forschung im deutschsprachigen Raum - State of the Art (pp. 147-157). Lengerich: Pabst.

Harzer, C., \& Ruch, W. (2012). When the job is a calling: The role of applying one's signature strengths at work. The Journal of Positive Psychology, 7, 362-371. https://doi.org/10.1080/17439760.2012. 702784.

Harzer, C., \& Ruch, W. (2013). The application of signature character strengths and positive experiences at work. Journal of Happiness Studies, 14, 965-983. https://doi.org/10.1007/s10902-012-9364-0.

Harzer, C., \& Ruch, W. (2014). The role of character strengths for task performance, job dedication, interpersonal facilitation, and organizational support. Human Performance, 27, 183-205. https://doi.org/ 10.1080/08959285.2014.913592.

Harzer, C., \& Ruch, W. (2015). The relationships of character strengths with coping, work-related stress, and job satisfaction. Frontiers in Psychology, 6, 165. https://doi.org/10.3389/fpsyg.2015.00165.

Harzer, C., \& Ruch, W. (2016). Your strengths are calling: preliminary results of a strengths-based onlineintervention to increase calling. Journal of Happiness Studies, 17, 2237-2256. https://doi.org/10. 1007/s10902-015-9692-y.

Harzer, C., Bezuglova, N., \& Weber, M. (2019). Incremental validity of character strengths as predictors of job performance beyond general mental ability and the Big Five. Manuscript under review.

Harzer, C., Mubashar, T., \& Dubreuil, P. (2017). Character strengths and strength-related person-job fit as predictors of work-related well-being, job performance, and workplace deviance. Wirtschaftspsychologie, 19(3), 23-38.

Heintz, S., \& Ruch, W. (2019). Character strengths and job satisfaction: differential relationships across occupational groups and adulthood. Applied Research in Quality of Life. https://doi.org/10.1007/ s11482-018-9691-3.

Kalyar, M. N., \& Kalyar, H. (2018). Provocateurs of creative performance: examining the roles of wisdom character strengths and stress. Personnel Review, 47, 334-352. https://doi.org/10.1108/PR-10-20160286.

Kong, D. T., \& Ho, V. T. (2016). A self-determination perspective of strengths use at work: examining its determinant and performance implications. The Journal of Positive Psychology, 11, 15-25. https:// doi.org/10.1080/17439760.2015.1004555.

Kristof, A.L. (1996). Person-organization fit: an investigative review of its conceptualizations, measurement, and implication. Personnel Psychology, 49, 1-49. https://doi.org/10.1111/j.1744-6570.1996. tb01790.x.

Kristof-Brown, A.L., \& Billsberry, J. (2013). Fit for the future. In A.L. Kristof-Brown \& J. Billsberry (Eds.), Organizational fit: Key issues and new directions (pp. 1-18). Oxford: Wiley \& Sons. https:// doi.org/10.1002/9781118320853.ch1.

Lavy, S., Littman-Ovadia, H., \& Boiman-Meshita, M. (2017). The wind beneath my wings: effects of social support on daily use of character strengths at work. Journal of Career Assessment, 25, 703-714. https://doi.org/10.1177/1069072716665861.

Linley, P. A. (2008). Average to A+: realizing strengths in yourself and others. Coventry: CAPP Press.

Linley, P. A., Nielsen, K. M., Gillett, R., \& Biswas-Diener, R. (2010). Using signature strengths in pursuit of goals: effects on goal progress, need satisfaction, and well- being, and implications for coaching psychologists. International Coaching Psychology Review, 5, 6-15.

Littman-Ovadia, H., \& Lavy, S. (2016). Going the extra mile: perseverance as a key character strength at work. Journal of Career Assessment, 24, 240-252. https://doi.org/10.1177/1069072715580322.

Littman-Ovadia, H., Lavy, S., \& Boiman-Meshita, M. (2017). When theory and research collide: Examining correlates of signature strengths use at work. Journal of Happiness Studies, 18, 527-548. https:// doi.org/10.1007/s10902-016-9739-8.

McQuaid, M. (2017). Positive psychology coaching: An approach for human flourishing. Organisationsberatung, Supervision, Coaching, 24, 283-296. https://doi.org/10.1007/s11613-017-0510-8.

Meyers, M.C., \& van Woerkom, M. (2017). Effects of a strengths intervention on general and work-related well-being: the mediating role of positive affect. Journal of Happiness Studies, 18, 671-689. https:// doi.org/10.1007/s10902-016-9745-x. 
Meyers, M. C., Adams, B. G., Sekaja, L., Buzea, C., Cazan, A.-M., Gotea, M., \& van Woerkom, M. (2019a). Perceived organizational support for the use of employees' strengths and employee well-being: a cross-country comparison. Journal of Happiness Studies, 20, 1825-1841. https://doi.org/10.1007/ s10902-018-0026-8.

Meyers, M.C., Dubreuil, P., \& Harzer, C. (2019b). Nurturing happiness at work through strengths use. Manuscript submitted for publication

Meyers, M. C., Kooij, D., Kroon, B., de Reuver, R., \& Van Woerkom, M. (2020). Organizational support for strengths use, work engagement, and contextual performance: The moderating role of age. Applied Research in Quality of Life. https://doi.org/10.1007/s11482-018-9702-4.

Meyers, M. C., van Woerkom, M., de Reuver, R., Bakk, Z., \& Oberski, D. L. (2015). Enhancing psychological capital and personal growth initiative: working on strengths or deficiencies? Journal of Counseling Psychology, 62, 50-62. https://doi.org/10.1037/cou0000050.

Miglianico, M., Dubreuil, P., Miquelon, P., Bakker, A. B., \& Martin-Krumm, C. (2019). Strength use in the workplace: a literature review. Journal of Happiness Studies. https://doi.org/10.1007/s10902-01900095-w.

Montano, D., Reeske, A., Franke, F., \& Hüffmeier, J. (2017). Leadership, followers' mental health and job performance in organizations: a comprehensive meta-analysis from an occupational health perspective. Journal of Organizational Behavior, 38, 327-350. https://doi.org/10.1002/job.2124.

Park, N., Peterson, C., \& Seligman, M.E.P. (2004). Strengths of character and well-being. Journal of Social and Clinical Psychology, 23, 603-619. https://doi.org/10.1521/jscp.23.5.603.50748.

Peterson, C., \& Seligman, M.E.P. (2004). Character strengths and virtues: a handbook and classification. New York: Oxford University Press.

Peterson, C., Park, N., \& Seligman, M.E.P. (2005). Assessment of character strengths. In G. P. Koocher, J. C. Norcross \& S. S. Hill III (Eds.), Psychologists' desk reference (2nd edn., pp. 93-98). New York: Oxford University Press.

Proyer, R. T., Gander, F., Wellenzohn, S., \& Ruch, W. (2013). What good are character strengths beyond subjective well-being? The contribution of the good character on self-reported health-oriented behavior, physical fitness, and the subjective health status. The Journal of Positive Psychology, 8, 222-232. https://doi.org/10.1080/17439760.2013.777767.

Proyer, R. T., Sidler, N., Weber, M., \& Ruch, W. (2012). A multi-method approach to studying the relationship between character strengths and vocational interests in adolescents. International Journal of Educational and Vocational Guidance, 12, 141-157. https://doi.org/10.1007/s10775-012-9223-x.

Ruch, W., Proyer, R.T., Harzer, C., Park, N., Peterson, C., \& Seligman, M.E. P. (2010). Values in action inventory of strengths (VIA-IS): adaptation and validation of the German version and the development of a peer-rating form. Journal of Individual Differences, 31, 138-149. https://doi.org/10.1027/ 1614-0001/a000022.

Seligman, M.E.P., \& Csikszentmihalyi, M. (2000). Positive psychology: an introduction. American Psychologist, 55, 5-14. https://doi.org/10.1037/0003-066X.55.1.5.

Weber, M. (2018). Character strengths in the context of positive schooling. In T.S. George, A. Kumar, N. T. Sudhes \& R. Sreehari (Eds.), Handbook on Character Strength Development: Theory, Research and Implications for Practice. New Delhi: SAGE.

van Woerkom, M., \& Meyers, M.C. (2019). Strengthening personal growth: the effects of a strengths intervention on personal growth initiative. Journal of Occupational and Organizational Psychology, 92, 98-121. https://doi.org/10.1111/joop.12240.

van Woerkom, M., Bakker, A.B., \& Nishii, L.H. (2016). Accumulative job demands and support for strength use: fine-tuning the job demands-resources model using conservation of resources theory. Journal of Applied Psychology, 101, 141-150. https://doi.org/10.1037/ap10000033. 


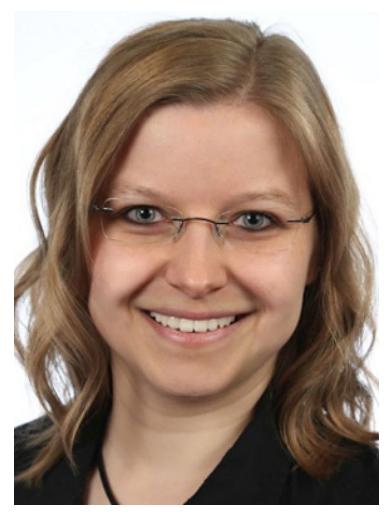

Dr. Claudia Harzer is a psychologist, researcher, lecturer, and speaker. Since 2012, she has served as a visiting professor at several universities in Germany and taught courses on psychological assessment, test development, positive psychology, and health promotion. Her research is primarily focused on the role of character strengths for various indicators of optimal functioning at work. 